\title{
The Role and Function of Poetry in Debate and Controversy
}

\author{
Judith Keßler, Ursula Kundert and Johan Oosterman
}

Martin Luther wrote his protest song Eyn newes lyed wyr heben an ('We start singing a new song'), when he first heard of the execution of the two Augustinian monks Hendrik Vos and Johannes van Esschen, who had been reluctant to abjure their evangelical faith, in Brussels in July 1523. In this song, he fiercely denounced the act and expressed his deep sorrow over the harsh repression of his adherents. ${ }^{1}$ It was both a critique and a remembrance aimed at moving people and encouraging them to resist the authorities. In the tenth stanza, inserted in most of the printed copies, the ashes of the executed are compared to the power of song to spread the new ideas despite oppression by the authorities:
Die aschen will nicht lassen ab, sie steubt ynn allen landen, Hie hilfft kein bach, loch, grub noch grab, sie macht den feynd zu schanden.
Die er ym leben durch den mord zu schweygen hat gedrungen,
Die mus er tod an allem ort mit aller stym und zungen Gar frolich lassen singen. ${ }^{2}$

Execution creates martyrs, and even though they cannot speak anymore, their ashes penetrate everything, as does the song about them. Luther, master of influencing public opinion, must have deliberately chosen the medium of song to send out his message. He knew how accessible it was, how easily and quickly it would spread, how the content would have a direct emotional impact, and how the melody would stick in the mind. When Luther wrote this song, he clearly intended it to be pervasive geographically and emotionally, and so it

1 Akerboom and Gielis (2005).

2 Luther (1923) 411-415. 
was. Some even risked their freedom or their lives by helping to promulgate Luther's songs: an old clothier was imprisoned for selling and singing them in the middle of Magdeburg in $1524{ }^{3}$ What began as a medium of protest transformed religious musical life, created collective memory, and shaped the identity not only of Luther's followers, but also of other political and religious groups in conflict. ${ }^{4}$

Of course, Luther was not the first to realize that song, or, from a broader perspective, poetry, was an excellent medium for spreading controversial points of view. There are manifold examples of this, the best known of which is the Rubempré affair: around the year 1465 Philip the Good, Duke of Burgundy, accused the French king of spreading slanderous songs. During Luther's time it was more evident than ever before that people were very much aware of the 'powers of poetry'. ${ }^{5}$ Andrew Pettegree has clearly and repeatedly demonstrated how the mechanisms of propaganda function and how songs take up a special position in this context. Songs are even more exceptional when placed in the textual culture of the early reformation: songs were passed on orally and not primarily through the printing press, of which Luther made ample use, and their form distinguishes them from most other publications. Luther excelled at turning vernacular prose into a highly effective medium to spread his ideas and reach new audiences. Poetry and especially songs, however, clearly had something extra to offer, as demonstrated by contemporary accounts of their effectiveness and the sheer numbers in which they were produced: no less than 35 songs are ascribed to Luther himself. More than ever, the song was both a weapon and a powerful instrument in constructing identities. Of course, this remains true well after the reformation and powerful poetry of that period was reused in new controversies. In a famous, but not historical, reconstruction of Luther composing his song Ein feste burg, ${ }^{6}$ Heinrich Heine sees this potential when he equals the song to the Marseillaise and foresees similar political uses for the near future:

Cet hymne, la Marseillaise de la réforme, a conservé jusqu'à ce jour sa puissance énergique, et peut-être entonnerons-nous bientôt dans des combats semblables ces vieilles paroles retentissantes et bardées de fer ${ }^{7}$

3 Eckert (2013) 97-98. Schlisske (1948) 36. For similar incidents in Bavaria, cf. Fisher (2014) 1-2.

4 Cf. Van der Poel et al. (eds) (2016). For Catholic identity shaped musically in counter-reformation Bavaria see Fisher (2014) 3 and passim. For the importance of a German song for religious emigrants to America see Holznagel's contribution in this volume.

5 Pettegree (2005) 40-75. See also the recently published Pettegree 2015.

6 Luther (1923) 518-520.

7 Heine DHA 18/1, 286. 
Nevertheless, we stop our inquiry at the beginning of the seventeenth century because the poetry landscape changes significantly with the reception of lyric forms from Antiquity and the Romance literatures such as the sonnet. ${ }^{8}$ This change is marked for Dutch and Flemish literature by the work of Daniel Heinsius, and for German literature by that of his pupil, Martin Opitz.

The question of why poetry is such a favourite medium during situations of social, societal, political and religious controversy was the central theme of the 2009 conference in Sankelmark. This volume constitutes its report in written form. ${ }^{9}$

We understand poetry in its broader sense of everything written in verse, but restrict our corpus to texts of moderate length, because the verse romance has already been studied intensively. The maximum length is indicated by the contribution by Levente Sélaf, who studies Hungarian historical songs that vary from 81 to 449 stanzas. ${ }^{10}$ Some contributors show how metre alone can play an important role in the unfolding of a controversy through different media. In most cases however, words and metre are accompanied by other forms, and it is the intention of this volume to show how their interplay shapes controversies. In social conflicts in general, a common topic has to be set, and divergent positions to it have to be taken. This can be done in prose, a practice well established in the late Middle Ages by the scholastic disputatio which spread well into the vernacular genres, too. In the disputatio, a question of deliberation sets the topic and the two positions are predefined by the possible answers 'yes' or 'no.'11 If we add the medium of verse to the words, the conflict can be intensified by using a metre that (by its traditional use or text) favours one side. In turn, using a metre accepted by both sides, or one contradicting the main aim of the words, can make the tension subtler. Thus, it is easily conceivable how the strategic deployment of rhyme, stanza, melody, and rhythm can add to the impact and play with the complexity of media used to express alliances.

As we focus on literary and musical form and media, the chosen controversies are secondary to our purpose. The poetry analysed addresses institutional

8 For the impact of renaissance forms in the Romance languages see Langer (2017).

9 Two contributions to the conference have been published separately: Folke Gernert, Preguntas y respuestas entre España y Francia, in: Bulletin of Hispanic Studies 91.8 (2014) 855-865. Miguel García-Bermejo Giner, "me pedís que escriba | arte de hacer comedias": Estrategia y contenido del Arte nuevo de Lope de Vega, in: Romanistisches Jahrbuch 6o (2010) 318-339.

10 See his contribution in this volume.

11 Cf. Gindhart and Kundert (2010) introduction. 
and national issues. By including a broad range of topics, we want to stress the importance of poetry for controversies, because it is used in such a variety of contexts. Nevertheless, fifteenth and sixteenth century societies were moved by other issues which are not considered in this volume, but for which we would like to encourage a similarly deep analysis of the use of literary and musical media.

A closer look at what happened in a cultural climate in which authors were able to choose between prose and verse can contribute to a better understanding of how poetry and literary media changed in the late Middle Ages and the early modern period. While the general forms through which controversies were expressed have recently been analysed for this era, ${ }^{12}$ there is still no profound and contextualized research on the verse versus prose debates of that time. Cases where disputes about verse and prose were linked to underlying controversies, thus possibly reflecting the background issues in terms of poetics, are especially interesting. The literary controversy presents an excellent opportunity to highlight other contentious points. The essays in this volume focus on the years between 1400 and 1625 , a period especially rich in controversies of all kinds. Their aim is to investigate why poetry was still used at a time when the shift towards prose was well underway and how verse contributed to the unfolding of political, religious and educational arguments. Thus, this volume provides a literary perspective that is seldom taken in German literature studies of this period, which is studied by medievalists on the one hand and modernists on the other. Collaborating with specialists in the field of Dutch literature, where disciplines are not divided in the same way, made it possible to minimize the polarizing effect of these two influences. Furthermore, existing research that predominantly focusses on the theological controversies surrounding Luther has to be contextualized within the use of verse in other

12 On their polemic nature in its various forms and for literary theoretical exploration of them, see Spoerhase 2007 and Bremer 2006, which focuses on history of science in relation to philology (like Spoerhase 2006, he explicitly defines the history of science as a history of conflict, as do Laureys and Simons 2010). Worstbrock and Koopman (1986) focus more on the essentials and nature of the controversies themselves. Entitled 'Formen und Formgeschichte des Streitens', their entire volume of literary discussions and debates provides analyses from different literary theoretical perspectives. The contributions to Bloemendaal, Van Dixhoorn and Strietman 2011 focus solely on the controversies of the early modern period. On the special case of pamphlets in Germany, see Harms and Schilling 2008, Smolinsky 2004 and Chrisman 1996; in the Netherlands, Duke 2003; in Great Britain, Raymond 2003. For the learned disputatio as a genre, it is especially worth mentioning Gindhart and Kundert (2010). In this volume, several forms are discussed from the context of the Middle Ages up until the eighteenth century. 
kinds of disputes. ${ }^{13}$ For these reasons, this volume aims to uncover the motivations and circumstances that led to the choice of poetry over prose for a variety of controversies.

Shortly after the year 1500 , half a century after the invention of the printing press and at the start of the reformation, authors started to make a conscious choice between prose and poetry. Two centuries before that, it was extremely rare to produce prose in the vernacular, as the non-scholarly textual culture was dominated by texts in verse. Prose was predominantly present in educational genres like encyclopaedias, homilies, and saints' lives, but there was a vast body of verse literature available as well, especially in vernacular languages. This changed in the late Middle Ages, although there were significant regional and genre-related differences in the pace and direction of this development. In his historical panorama of the thirteenth century, Joachim Heinzle speaks about a 'breakthrough of vernacular prose' in German literature that began with juridical, historical, and pious works being translated from Latin prose texts, which gradually nudged poetry into 'specialized and marginal fields' of writing culture. $^{14}$

Geographically, this development started in the Romance literatures. The first prose romance with a large impact on other European literatures was the French Lancelot en prose. The culturally rich region of the Lower Rhine might have played a major role in the international unfolding of this process: the link between the French and the Middle High German versions of the first story in the text was probably a Middle Dutch work that is now lost. ${ }^{15}$ Research has emphasized the importance of this region as a transition area between the Romance and German languages and cultures. ${ }^{16}$ In addition to the early reception of Lancelot en prose, the prose text of the Niederrheinisches Moralbuch can also be placed in the Lower Rhine region around $1300 .{ }^{17}$ Our volume focusses on the process from a translingual and transcultural perspective, with special emphasis on the context in the German lands and in the Low Countries.

The movement towards more prose literature was neither linear nor uncontested. Commissioned at the start of this development, the prologue of the

\footnotetext{
13 For the forms of early modern controversies between Catholics and Lutherans see Bremer 2005, Bagchi 1991, and Stolt 199o. For the style of discussion between Luther, Erasmus, and Thomas More see Ribhegge 1997. Luther's reaction is discussed extensively in Akerboom and Gielis 2005 .

14 Heinzle (1994) 205-208.

15 Heinzle (1994). 224.

16 Tervooren (2005), esp. 15-26: 'Methodische Vorüberlegungen: Raum, Zeit, Quellenlage'.

17 Tervooren (2005), 26o-262.
} 
German Lucidarius mentions that Henry the Lion requested a work an rimen ('without rhymes') from his chaplains, because they ensolden nicht schriben wan die wahrheit ('should not write anything but the truth') in the text; the main arranger comments stiffly that lack of talent on his part was not the reason. ${ }^{18}$ This controversy shows that the discussion of key concepts in poetics is closely linked to the centuries-long shift from verse to prose, ${ }^{19}$ at the same time demonstrating that such disputes are extremely context sensitive. A certain topic might be heavily contested in one case, while going almost completely unnoticed in another. In Middle Dutch, the Elucidarius has been translated, reworked and otherwise reused in both verse and prose. ${ }^{20}$

The work of mystic Jan of Ruusbroec (1293-1381) from Brabant provides a good illustration of the various tensions between rhyming verse and prose, the public's appreciation —or lack thereof-for either prose or poetry and the way authors dealt with these circumstances. His treaty Vanden VII sloten (Of the seven locks) is mostly written in prose, but the fourteen-line introduction in which he briefly outlines the subject of the text is in rhyming verse. He also addresses a 'dear sister', Clare Margaret of Meerbeke, the nun for whom he wrote the piece. Towards the end of the introduction he says:

$\mathrm{Nu}$ willic rimen laten bliven,

Ende sonder decsel de waerheit scriven.

Now I will have done with rhymes

And write the truth without trimming. ${ }^{21}$

If he was so convinced that prose was preferable to poetry, why did he not write in that form from the beginning? Based on his research into Spiritual Espousals, also by Ruusbroec, Geert Warnar argues that Ruusbroec constructed his texts with the utmost care, even on a linguistic level. This was to make sure that the reader would be able to follow his lead and come to achieve deep mystical

18 A-Prolog nach der Hs. Berlin, Staatsbibliothek - Preußischer Kulturbesitz, Ms. germ. $8^{\circ}$ 56, hg. Gottschall/Steer 1994, S. 102* Z. 10-S. 104* Z. 2.

19 Heinzle (1994) 167; Bremer (2006) 9-16.

20 Klunder (2005) passim; cf. Lie (1994) passim, where the debate on verse vs prose is described very well, with attention to the Elucidarius and many other Middle Dutch texts. Lie is one of the first to pay attention to literatures other than the French, focussing on the Dutch in particular. Based on numerous examples, she works out how the debate developed between the thirteenth and fifteenth centuries, how and why the authors took the stances they did.

21 Ruusbroec (1981) 100-101. 
insights. A proper introduction was meant to evoke 'feelings of interiorization, reverence and devotion, ${ }^{22}$ which would make the reader willing to follow the author through the complex text.

The same careful textual build-up can be found in the introduction to Van den VII sloten. It is unthinkable that Ruusbroec only wrote those fourteen lines of poetry to make the text more pleasing to the eye. Rhyme did not only have an aesthetic function, but probably also served to make the text more accessible to the intended reader. Margaret of Meerbeke likely did not know any Latin and mostly came into contact with vernacular literature. Contrary to Ruusbroec's work, which mostly consists of prose texts, vernacular literature around 1350 was often limited to verse, which must have been the most familiar form to Margaret of Meerbeke. Ruusbroec seems to have assumed this as well, which is why he started with a short rhyming verse introduction to make the beginning easier to remember-rhyme functions as a strong mnemonic device - and to explain why he would continue in prose. In other words, the opening verses serve both as an introduction to the text and as an aid to studying it. As such, this example perfectly illustrates the transition from poetry to prose.

Given the decline of poetry, it might be surprising to learn that it was still used during the late Middle Ages and Renaissance. While Mühlethaler characterizes the use of verse in thirteenth to seventeenth century French literature as 'writing against the current, ${ }^{23}$ the same cannot be said of Dutch and German literature without immense exaggeration. Good examples of the continuous preference for poetry, or rather the impossibility of putting it aside quickly, are the publishing strategies of early Dutch printer publishers. Many a medieval romance was adapted to the new medium of the printed word and texts in verse were rewritten in prose. The new form, however, clearly did not work for an audience used to oral performances. The prose romance of Floris ende Blancefloer, printed in Antwerp in 1518 and adapted from the Flemish verse romance, provides the reader with more than the original: at dramatic moments in the story, poems were added in the style of the rederijkers (rhetoricians), innovative poets from the Low Countries in the late fifteenth and early sixteenth centuries. The poems provide both a modern touch and a reference to the past by reminding the reader of early orally delivered romances and providing moments of emotional and moral reflection. Verse still had a function and the publishers must have been aware of its attractive qualities for large parts of their audience.

22 Warnar (2007) 117.

23 The title of Mühlethaler (2010). 
This volume will take several approaches to the question of why poetry was still preferred during a time when prose was the dominant form, especially in major political and religious debates of the fifteenth and sixteenth centuries. The case studies discussed here provide a reasonably broad European perspective, embracing multiple geographical areas and poetic subgenres. The authors may focus on a specific event and public reactions to it (Sélaf, Steinkamp and Willcocks), or on a particular subgenre (Coigneau, Van Gemert). Some articles start from a broad perspective, while others start with a single text (Keßler). No matter what approach they take, all contribute to a deeper understanding of the fascinating phenomenon of certain genres being chosen for certain types of debates.

The first two contributions provide a theoretical framework that explains the underlying mechanisms that make poetry, and song in particular, such a good medium for reinforcing certain debates. Franz Josef Holznagel aptly demonstrates how the form and melody of songs might equate to taking a stance, in certain scenarios, as these aspects can be used to evoke a thematic field without explicitly mentioning it. Contrafactures not only take on formal aspects of their earlier incarnations, but also become associated with an entire framework of meaning and values. Holznagel also shows that the continued success of poetic texts and models is due to a combination of factors, not simply the melody and mnemonic properties of rhyming verse. Dieuwke van der Poel adds to this argument that the impact of music is not to be underestimated in this context. She points out several introductions to texts written around $155^{\circ}$ in which the powerful effect of songs is mentioned and even warned against, particularly in song collections that might contain texts with 'abominable' worldly content. Dieuwke van der Poel asks herself what lies behind this fear and turns to cognitive sciences to provide insight into the mental processes that contribute to making the song such a powerful medium. How come music has such a strong emotional impact? Why are melodies so easily retained in human memory? Her findings show that there is much to be gained by exploring the areas where social sciences and literary history meet, as has also become clear from research into the mediality and performativity of textual culture.

The most striking group of texts that are studied in this volume are songs about contemporary events. In German texts like these are called Ereignisdichtung, which roughly translates as occasional or political poetry. From an international perspective, geuzenliederen - songs that describe and commemorate numerous events from the Dutch revolt - form another notable group of texts. While they have been properly and carefully inventoried, research into the way they functioned has barely got off the ground. For too long they have 
been viewed as a primarily historical source, even though their reliability is questionable. In recent years, however, more attention has been paid to their role in forming cultural memory and identity, as well as their potential place in early modern forms of propaganda.

Levente Sélaf and Philipp Steinkamp focus heavily on such occasional poetry. Sélaf compares and contrasts Hungarian, German and Italian songs about historical events and demonstrates how they change from simply reporting the event to shaping identities. He shows that this process is subtle: the memory of the events is cultivated by using earlier models from older heroic poetry and referencing popular poetry. The new song joins a tradition that provides it with an air of authority, which in turn ensures that 'historical truth becomes poetic truth.' Steinkamp writes about songs that deal with the war of the succession of Landshut, the Landshuter Erbfolgekrieg. He, too, demonstrates how replicating melodies and clear textual references place the new songs in an existing discourse, thus increasing the songs' validity. These effects seem to be especially strong in song form because songs are excellent vehicles for emotionally charged content (much better than the Sprüche, paired texts in rhyming verse focussing on the same event). Both Sélaf and Steinkamp demonstrate that songs about historical events contribute more to creating an emotional connection with the occurrence than topical, argumentative debates do. Songs, one might propose, contribute to creating a sense of community over a longer period of time, which in turn shapes the community's identity.

One of the quintessential identity-forming geuzenliederen is the song about William of Orange, now the national anthem of the Netherlands, and one of the most widely distributed pieces during the Dutch revolt. At first glance this might seem strange, as it is written in the first person singular and contains direct speech by a historical figure. Guillaume van Gemert's contribution focusses on songs like this particular geuzenlied in which historical figures proclaim the words. One of the cases he uses to construct his argument concerns the William of Orange song and two later versions that feature his sons Maurits and Frederik Hendrik. The latter two songs, consciously placed in the tradition of William's original version, keep the heritage alive and purposefully use the image of the father to influence the perception of the sons. In such cases it is not surprising that song was the medium chosen to get the clearly ideological message across. In contrast, the songs about Henry the Younger and BrunswickWolfenbüttel present the audience with an anti-hero, creating a verkehrtes Heldenepos ('inverted heroic epic'). The mechanisms at work are similar to the ones in songs about regular heroes, the earliest and possibly most direct examples of which date back to the fifteenth century (for instance, the song about Mary of Burgundy, who addresses her loved ones from her deathbed). Of 
course, mechanisms like identification function slightly differently here, but the emphatic appeal to the audience is just as strongly present.

The sixteenth century is the age of the debate in verse. In the battle of words surrounding Luther, Anna Bijns, a poet from Antwerp, presents a striking voice. She uses the most authoritative poetic genre of the rederijkers to launch sharp attacks on Luther. Not, argues Judith Keßler, to enter into debate with him, but rather to encourage Catholics to have faith and maintain courage. She uses the refrein (a specific and complex poetic form derived from the French ballad), which is indicative of the dominant position that this poetic form has and the authority it exudes. As Dirk Coigneau states, the refrein is the rhetoricians' preferred form for presenting moralizing content. Its complexity and some of its formal characteristics present the poet with ample opportunity to emotionally involve the audience in their argument through repetition, metaphor and numerous parallelisms. While Keßler uses one poem to demonstrate the role of the bound form in the workings of the debate, Coigneau investigates the function of the refrein in the much broader context of rederijker stagecraft. His findings show, as mentioned above, that form is explicitly tied to content. As refrains are formally complex, they are especially suited to presenting serious subject matter, while short rondos and songs were much preferred in comedies as they were considered to be more popular and appear more realistic on stage - a character suddenly breaking into song is much more plausible then someone starting to recite a long poem. As soon as the latter occurs, the audience will immediately know something important is going on. Like Keßler, Coigneau also shows that the refrein had developed into an excellent tool to ensure the audience was emphatically and emotionally involved. Rhetoricians are, however, quite specific to the Low Countries, and even though they have close ties to the humanist movement, they still have their own discourse and forms of expression.

While it is reasonably well known that poetry held great appeal in humanist circles, the form that this fascination took has rarely been studied. Two contributions to this volume focus on interesting cases, from the Low Countries and Königsberg. Groenland talks about Murmellius, whose work is better known for his alleged murder at the hands of the subject of one of his literary attacks rather than the form and content of his poems. Murmellius was convinced of poetry's didactic value and often used it for that purpose, even though the genre had a bad reputation in the educational sector. The form of the poem offered authors plenty of opportunity for writing sharp satire and controversy, and Murmellius makes much use of these aspects in most of his works. It seems highly likely that his humanist and polemic temperament strongly influenced his preference for poetry. 
Regina Toepfer focusses her attention on the extraordinary Latin translation of Basil of Caesara's sermon De individia, which first appeared in Königsberg in 1580. Josua Thomae, the translator, turned prose into poetry and changed a primarily religious text into a plea for support for the university. The translation was written in response to a turbulent situation, to move the public to act, and Thomae must have thought poetry would be the best medium to achieve this effect. As a form, Toepfer concludes, poetry mimics orally delivered texts, which makes the audience feel more directly involved: the phrases and repeated appeals to the reader (or supposed listener) give poems a strong emphatic character. Poetry evoked a different reception and was able to affect its audience on a different and more emotional level than prose did. The translation was widely circulated, which suggests it was a great success. Whether this was due to its form or subject matter is, of course, difficult to determine, but whichever is the case, Thomae managed to reach his audience and his goals.

The final three essays emphasize the relationship between poetry, the public, the poet and the commissioner. Existing receptions of older poetry and music are strategically deployed to form these relationships. Signer RotterBroman shows that intertextual references to older poetical authorities like Dante do not have to represent a conservative positioning, but-associated with a similar musical play between allusion and invention-form part of the composer's innovative strategy. In this way, the madrigal Godi Firenze, composed by Paolo da Firenze, celebrates the Florentine victory over Pisa in 1406 with innovative sparks in both words and music —a delight for learned circles. Unlike in the cases analysed by Holznagel, this song alludes to various genres, and the allusions differ for words, metre, and music. The musical and literary crossover is part of the innovative strategy. Samuel Pakucs Willcocks discusses two of Michael Beheim's song collections. They contain poetic versions of prose texts and seem to have been commissioned by the University of Vienna and a group of nobles, yet there is no hard evidence to support this theory. Regardless, the ideological, almost propaganda-like tone of the religious songs is all too clearly present, not least in the case of the anti-Semitic texts. Beheim's adaptation of the original prose is more than just a remediation of the text. Adjustments in the content, however small, change the perspective, political and religious tone. Changing songs to serve one particular context rather than another usually coincides with shifting social circumstances, a pattern that is repeated in nearly all the works discussed in this volume.

Alisdair A. MacDonald provides an overview of the extraordinary poetic flourishing in sixteenth-century Scotland. This contrasts notably with earlier periods in Scotland, but poetry boom during the sixteenth century seems to be 
a much broader European development spurred on by the reformation. MacDonald's article also shows that during this century there were quite a few such pan-European developments: the nature of the manuscripts that continued to co-exist alongside printed song collections, the popularity of the contrafact, rhyming psalms, and the dominant presence of occasional poetry. This last development would continue to intensify during the course of the century. As MacDonald says, 'the lyric has become the handmaid of factional politics,' and while poetry grew more political (or at least more socially involved), the author (or commissioner) looking to influence opinion continued to make use of poems and songs.

Beheim's songs not only derive their performative strength from the fact that they were, or could be, sung, but also from their explicit song-like character. They evoke associations with recitals, at which the person of the poet is often present, and even if they are read they have the emotional and persuasive force of a song that is sung. This phenomenon occurred more and more during the fifteenth and sixteenth centuries, which reinforces the idea that the poetic form was assumed to have an emotional, argumentative and emphatic effect that was not attributed to prose forms to the same extent. This point of view would certainly have contributed to the prevalent preference for poetry during the tumultuous transitional centuries between the Middle Ages and the early modern era. Thus, we now have a better understanding of the developments that led to poetry becoming and remaining such a beloved medium during the centuries when Europe reshaped itself.

\section{Bibliography}

\section{Primary Literature}

Luther, M. 1923. Werke, vol. 35: Die Lieder. ed. W. Lucke et al., Weimar.

Heine, H. 1979. De l'Allemagne. Nouvelle édition 1855. In idem, Historisch-kritische Gesamtausgabe der Werke [Düsseldorfer Ausgabe], vol. 18/1, ed. Manfred Windfuhr, Hamburg: 253-442 (http://www.hhp.uni-trier.de/Projekte/HHP/Projekte/HHP/wer ke/baende/Do8/accessed on 28 April 2018).

\section{Research Literature}

Akerboom, D., and M. Gielis 2005. “A New Song Shall Begin Here ...”. The Martyrdom of Luther's Followers among Antwerp's Augustinians on July 1, 1523 and Luther's Response. In More than a Memory. The Discourse of Martyrdom and the Construction of Christian Identity in the History of Christianity, ed. J. Leemans. Leuven: 243-270. Altenburg, D., and R. Bayreuther (eds) 2012. Musik und kulturelle Identität. Kassel. 
Bagchi, D.V.N. 1991. Luther's earliest opponents. Catholic controversialists, 1518-1525. Minneapolis.

Bithell, C. 2014. A different voice, a different song. Reclaiming community through the natural voice and world song. Oxford/New York.

Bitzan, W. 2010. Auswendig lernen und spielen. Über das Memorieren in der Musik. Frankfurt am Main/New York (European university studies. Series 36, Musicology, 26o).

Bloemendal, J., A. van Dixhoorn, and E. Strietman (eds). 2011. Literary Cultures and Public Opinion in the Low Countries, 1450-1650. Amsterdam (Brill's Studies in Intellectual History 197).

Bremer, K. 2005 Religionsstreitigkeiten. Volkssprachliche Kontroversen zwischen altgläubigen und evangelischen Theologen im 16. Jahrhundert. Tübingen (Frühe Neuzeit 104).

Bremer, K. 2006. Philologie und Polemik. Ein Forschungsabriß zum wissenschaftsgeschichtlichen Status der Kontroversen in der Frühen Neuzeit. Geschichte der Germanistik. Mitteilungen 29-30: 9-16.

Bremer, K., and C. Spoerhase 2011. Gelehrte Polemik. Intellektuelle Konfliktverschärfungen um 1700. Frankfurt am Main.

Brokaw, K.S. et al. 2011. Tudor Musical Theater. Staging Religious Difference From Wisdom to The Winter's Tale. Ithaca, New York.

Chrisman, M.U. 1996. Conflicting visions of reform. German lay propaganda pamphlets, 1519-1530. Atlantic Highlands, New Jersey.

Duke, A.C. 2003. Posters, Pamphlets and Prints. The Ways and Means of Disseminating Dissident Opinions on the Eve of the Dutch Revolt. Dutch Crossing 27: 23-44.

Eckert, E. 2013. Reformatorische Risiken und Nebenwirkungen auf Kirchenlieder der Gegenwart. In Ein neues Lied wir heben an. Die Lieder Martin Luthers und die dichterisch-musikalische Wirkung der Reformation, ed. V. Gallé. Worms: 97-118.

Fisher, A.J. 2014. Music, piety, and propaganda. The soundscapes of counter-reformation Bavaria. New York (The new cultural history of music).

Fumerton, P. (ed.) 2010. Ballads and broadsides in Britain, 1500-1800. Farnham etc.

Gallé, V. (ed.) 2013. Ein neues Lied wir heben an. Die Lieder Martin Luthers und die dichterisch-musikalische Wirkung der Reformation. Worms.

Gasch, S., and S. Tröster (eds) 2013. Senfl-Studien. Tutzing (Wiener Forum für ältere Musikgeschichte 7).

Geck, M. 2017. Luthers Lieder. Leuchttürme der Reformation. Hildesheim/Zürich/New York.

Gindhart, M., and U. Kundert (eds). 2010. Disputatio 1200-1800. Form, Funktion und Wirkung eines Leitmediums universitärer Wissenskultur. Berlin/New York.

Harms, W., and M. Schilling 2008. Das illustrierte Flugblatt der frühen Neuzeit. Traditionen, Wirkungen, Kontexte. Stuttgart. 
Heinzle, J. 1994. Wandlungen und Neuansätze im 13. Jahrhundert. Tübingen (Geschichte der deutschen Literatur von den Anfängen bis zum Beginn der Neuzeit II/2).

Jost, W. 2006. Das Frankfurter Musikleben im Zeitalter der Reformation. Jacobsdorf.

Kadelbach, A. 2017. Paul Gerhardt im Blauen Engel. Und andere Beiträge zur interdisziplinären Kirchenlied- und Gesangbuchforschung. Tübingen (Mainzer Hymnologische Studien 26).

Klausnitzer, R. 2007. Kontroversen in der Literaturtheorie-Literaturtheorie in der Kontroverse. Bern (Publikationen zur Zeitschrift für Germanistik. Neue Folge 19).

Klunder, N. 2005. 'Lucidarius'. De Middelnederlandse Lucidarius-teksten en hun relatie tot de Europese traditie, Amsterdam (Diss. Leiden 2005).

Koldau, L.M. 2005. Frauen-Musik—Kultur. Ein Handbuch zum deutschen Sprachgebiet der Frühen Neuzeit. Köln/Wien.

Kurzke, H. and Schäfer, Ch. (eds) 2010. Kirchenlied und Kultur. Tübingen (Mainzer Hymnologische Studien 24).

Lambert, E. 2017. Singing the resurrection. Body, community, and belief in Reformation Europe. New York.

Lambert, E.M. 2018. Singing the resurrection. Body, community, and belief in reformation Europe. New York.

Langer, U. 2017. Lyric in the Renaissance. From Petrarch to Montaigne. Cambridge.

Laureys, M., and R. Simons (eds) 2010. Die Kunst des Streitens. Inszenierung, Formen und Funktionen öffentlichen Streits in historischer Perspektive. Bonn.

Leaver, R.A. 2017. The whole church sings. Congregational singing in Luther's Wittenberg. Grand Rapids, Michigan (Calvin Institute of Christian Worship liturgical studies series).

Lehtonen, T.M.S., and L. Kaljundi (eds.) 2016. Re-forming Texts, Music, and Church Art in the Early Modern North. Amsterdam (Crossing boundaries, 2).

Letellier, R.I. 2017. The bible in music. Newcastle upon Tyne.

Lie, O.S.H. 1994. What is Truth? The Verse-Prose Debate in Medieval Dutch Literature. Queeste 1: 34-65 (online: http://www.dbnl.org/tekst/lie_oo2what o1_o1/lie_oo2whato1_o1_ooo1.php accessed on 1 May 2018).

McShane, A. 2016. Drink, song and politics in early modern England. Popular Music 35: 166-19o. DOI: 10.1017/So261143016oooo27.

Meyer, U., R. Simanowski, and Ch. Zeller. 20o6. Transmedialität. Zur Ästhetik paraliterarischer Verfahren. Göttingen.

Mühlethaler, J.-C. 2010. Vers statt Prosa. Schreiben gegen den Strom im Frankreich des ausgehenden Mittelalters. Chloe. Beihefte zur Daphnis 42: 163-182.

Newman, S. 2007. Ballad collection, lyric, and the canon. The call of the popular from the Restoration to the New Criticism. Philadelphia.

Paech, J. 2008. Intermedialität-analog, digital. Theorien, Methoden, Analysen. München. 
Pettegree, A. 2005. Reformation and the Culture of Persuasion. Cambridge.

Pettegree, A. 2015. Brand Luther. How an Unheralded Monk Turned His Small Town into a Center of Publishing, Made Himself the Most Famous Man in Europe-and Started the Protestant Reformation. New York.

Plumley, Y. 2011. Citation, intertextuality and memory in the Middle Ages and Renaissance. Exeter.

Poel, D. van der, L.P. Grijp, and W. van Anrooij (eds). 2016. Identity, intertextuality and performance in early modern song culture. Leiden.

Quitslund, B. 2008. The Reformation in Rhyme. Sternhold, Hopkins and the English Metrical Psalter, 1547-1603. Florence (St Andrews Studies in Reformation History).

Rajewsky, I.O. 2002. Intermedialität. Tübingen (чтв für Wissenschaft Medien- und Kommunikationswissenschaft, 2261).

Rasch, R. 2017. [Review of] Identity, Intertextuality, and Performance in Early Modern Song Culture. Dieuwke van der Poel, Louis Peter Grijp, and Wim van Anrooij, eds. Renaissance quarterly 70:1192-1193.

Rasch, R. (ed.) 2005. Music publishing in Europe 1600-1900. Concepts and issues; bibliography. Berlin (The circulation of music 1).

Rasch, R. 1981. Aspects of the perception and performance of polyphonic music. Utrecht. Raymond, J. 2003. Pamphlets and Pamphleteering in Early Modern Britain. Cambridge.

Ribhegge, W. 1997. Kontakte und Kontroversen. Martin Luther, Erasmus von Rotterdam und Thomas More. In Europa. Wiege des Humanismus und der Reformation, ed. H. Boventer and U. Baumann. Frankfurt am Main: 111-129.

Rödding, G. 2015. Ein neues Lied wir heben an. Martin Luthers Lieder und ihre Bedeutung für die Kirchenmusik. Neukirchen-Vluyn.

Rothenberger, E., and L. Wegener (eds) 2017. Maria in Hymnus und Sequenz. Interdisziplinäre mediävistische Perspektiven. Berlin (Liturgie und Volkssprache, 1).

Ruusbroec, Jan van. 1981. Vanden seven sloten. Intr. and ed. by G. de Baere. Tielt/Leiden (Studiën en tekstuitgave van Ons Geestelijk Erf, Part Xx, 2).

Schlisske, O. 1948. Handbuch der Lutherlieder, Göttingen.

Smolinsky, H. 2004. Dialog und kontroverstheologische Flugschriften in der Reformationszeit. In Dialog und Gesprächskultur in der Renaissance, eds. H.B. Guthmüller, and W.G. Müller. Wiesbaden: 277-291.

Spoerhase, C. 2006. Wissenschaftsgeschichte als Konfliktgeschichte. Am Beispiel von Kontroversen in der Literaturtheorie. Geschichte der Germanistik. Mitteilungen 2930: $17-24$.

Spoerhase, C. 2007. Kontroversen. Zur Formenlehre eines epistemischen Genres. In Kontroversen in der Literaturtheorie / Literaturtheorie in der Kontroverse, ed. R. Klausnitzer and C. Spoerhase. Bern: 49-92. (Publikationen zur Zeitschrift für Germanistik 19).

Stolt, B. 199o. Luther-Kontroversen. Zeitschrift für deutsche Philologie 109: 402-414. 
Talkner, K. 2012. Singen und Sammeln. Liedpraktiken in den Lüneburger Klöstern der Frühen Neuzeit. Hannover (Quellen und Darstellungen zur Geschichte Niedersachsens 134).

Tervooren, H. 2005. Van der Masen tot op den Rijn. Ein Handbuch zur Geschichte der mittelalterlichen volkssprachlichen Literatur im Raum von Rhein und Maas. Berlin.

Tischler, H. 1995. Mode, Modulation, and Transposition in Medieval Songs. The Journal of Musicology 13: 277-283. DoI: 10.2307/764108.

Trocmé-Latter, D. 2016. The Singing of the Strasbourg Protestants, 1523-1541. London (St Andrews Studies in Reformation History).

Wagner Oettinger, R. 2004. Music as propaganda in the German Reformation. Aldershot etc. (St Andrews Studies in Reformation History).

Wagner Oettinger, R. 2017. Music as propaganda in the German Reformation. New York.

Warnar, G. 2007. Ruusbroec. Literature ans Mysticism in the Fourteenth Century. Leiden (Brill's Studies in Intellectual History 150).

Way, L.C.S., and S. McKerrell. 2017. Music as multimodal discourse. Semiotics, power and protest. London etc. (Bloomsbury advances in semiotics).

Wetzel, R.D., and E. Heitmeyer. 2013. Johann Leisentrit's Geistliche Lieder und Psalmen, 1567. Hymnody of the Counter-Reformation in Germany. Madison, New Jersey etc.

Worstbrock, F.J., and H. Koopmann (eds). 1986. Formen und Formgeschichte des Streitens. Der Literaturstreit. Tübingen (Kontroversen, alte und neue, Bd. 2. Akten des VII. Kongresses der IVG). 